\title{
Keragaman Stomata Okra (Abelmoschus esculentus L. (Moench)
}

\section{Okra (Abelmoschus esculentus L. (Moench) Stomatal Variability}

\author{
Sulassih $^{1}$, Joko Mulyono ${ }^{2}$, Muhamad Syukur ${ }^{1,3^{*}}$, Sofyan Zaman ${ }^{3}$, Muharama Yora ${ }^{4}$, Abdul Hakim ${ }^{3}$ \\ 'Pusat Kajian Hortikultura Tropika, Lembaga Penelitian dan Pengabdian pada Masyarakat Institut Pertanian Bogor, \\ Jl. Raya Pajajaran, Kampus IPB Baranangsiang, Bogor, Indonesia \\ ${ }^{2}$ PLP Penyelia Departemen Agronomi dan Hortikultura, Fakultas Pertanian, Institut Pertanian Bogor \\ ${ }^{3}$ Departemen Agronomi dan Hortikultura, Fakultas Pertanian, Institut Pertanian Bogor \\ ${ }^{4}$ Program Studi Pemuliaan dan Bioteknologi Tanaman, Fakultas Pertanian, Sekolah Pascasarjana, Institut Pertanian Bogor \\ Jl. Meranti, Kampus IPB Dramaga, Bogor 16680, Indonesia
}

Diterima 22 Mei 2018/Disetujui 11 Juni 2018

\begin{abstract}
Okra (Abelmoschus esculentus L. (Moench.) is high nutrition compound potential for diabetes and alzheimer. Yield is one of the characters have to improve in plant breeding program through stomatal characterization. The variability for 14 genotypes showed significantly for stomatal length, stomatal width, epidermal cell number, chloroplast number, stomatal number, stomatal index and stomatal density. Stomatal density for P2 was $256.80 \mathrm{~mm}^{2}$ that was non significant with Zahira $\left(265.31 \mathrm{~mm}^{2}\right)$ and Naila $\left(204.08 \mathrm{~mm}^{2}\right)$. Genotypes P2, Zahira and Naila showed low stomatal density that mean efficiency for water management in leaves. The high stomatal index causing high photosynthesis and high yield. Stomatal index were high for genotypes P1 (40.31) and P2 (35.69). Naila has low stomatal index but Zahira as significant as genotype P2.
\end{abstract}

Keyword : density, index, genotype, Naila, Zahira

\section{ABSTRAK}

Okra (Abelmoschus esculentus L. (Moench.) merupakan sumber nutrisi yang berpotensi untuk menurunkan resiko penyakit diabetes dan alzheimer. Perakitan varietas okra (Abelmoschus esculentus L. (Moench.) diarahkan kepada peningkatan produktivitas, Evaluasi sifat-sifat unggul dari aksesi okra diperlukan sebagai sumber informasi pengembangan suatu bahan tanam melalui observasi morfologi stomata. Evaluasi keragaman stomata empat belas genotipe okra menunjukkan bahwa genotipe okra yang diuji berpengaruh sangat nyata pada karakter panjang stomata, diameter stomata, jumlah epidermis, jumlah kloroplas, jumlah stomata, index stomata dan kerapatan stomata pada taraf alpa 1\%. Kerapatan stomata tetua P2 mencapai $256.80 \mathrm{~mm}^{2}$ dan tidak berbeda nyata dengan genotipe Zahira $\left(265.31 \mathrm{~mm}^{2}\right)$ dan Naila $\left(204.08 \mathrm{~mm}^{2}\right)$. Tetua $P 2$, Zahira dan Naila memiliki kerapatan stomata yang rendah sehingga meningkatkan efisiensi penggunanaan air. Index stomata yang tinggi dapat meningkatkan fotosintesis dan hasil produksi. Nilai index stomata genotipe tetua P1 (40.31) dan P2 (35.69) tinggi. Genotipe Naila memiliki index stomata rendah (28.37), sedangkan genotipe Zahira (36.96) tidak berbeda nyata dengan tetua $P 2$.

Kata kunci : genotipe, index, kerapatan, Naila, Zahira

\section{PENDAHULUAN}

Okra (Abelmoschus esculentus L. (Moench.) merupakan sumber protein, lemak, serat dan mineralmineral dibutuhkan oleh tubuh, yaitu kalium, natrium, magnesium, kalsium, besi, dan seng terutama pada bagian biji. Biji okra sangat baik diolah menjadi sereal sarapan. Biji

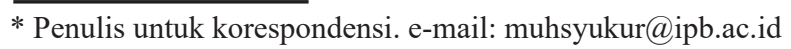

okra mengandung antioksidan, poliphenol, dan flavonoid, sehingga dapat meringankan keletihan serta mencegah stress oksidatif dan berpotensi untuk menurunkan resiko penyakit diabetes dan Alzheimer (Ikrarwati dan Rokhmah, 2016). Okra (Abelmoschus esculentus L. (Moench.) adalah termasuk tanaman menyerbuk silang yang penyerbukan sendirinya cukup besar karena polen dan stigma berada dalam satu bunga. Perakitan varietas okra diarahkan kepada peningkatan produktivitas, daya adaptasi dan peningkatan kandungan antosianin, sekaligus mampu beradaptasi dengan baik di Indonesia seperti okra ungu varietas Zahira IPB dan okra hijau varietas Naila IPB yang merupakan 
koleksi Pusat Kajian Hortikultura Tropika (PKHT) LPPM IPB dan Departemen Agronomi dan Hortikultura (AGH) Fakultas Pertanian IPB hasil persilangan dua tetua yaitu tetua betina merupakan donor ukuran buah besar dan tetua jantan merupakan donor warna ungu.

Produktivitas yang tinggi tentunya tidak terlepas kaitannya dengan organ tanaman yaitu daun. Fungsi daun yang utama adalah sebagai tempat terjadinya fotosintesis serta mengekspor hasilnya ke seluruh bagian tanaman. Stomata pada daun berfungsi sebagai jalan masuknya $\mathrm{CO}_{2}$ yang masuk ke daun untuk fotosintesis (Darmawan dan Baharsjah, 2010), sehingga semakin banyak jumlah stomata, maka produksi hasil semakin tinggi (Sarwar et.al., 2013). Stomata dapat pula digunakan untuk (1) mengindikasikan ketahanan terhadap penyakit penyakit bercak bakteri (bacterial blight) yang disebabkan oleh Xanthomonas axonopodis pv. Punicae pada tanaman seperti pada tanaman buah delima (Priya et al., 2016), (2) karakter anatomi stomata dapat digunakan untuk identifikasi, klasifikasi, dan penentu kekerabatan tumbuhan (Hafiz et al., 2013) dan (3) identifikasi tingkat ploidi yaitu semakin tinggi tingkat ploidi maka semakin besar ukuran sel dan stomatanya seperti pada pisang triploid mempunyai ukuran sel epidemis dan stomata lebih besar (Damayanti, 2007) dan jeruk tetraploid memiliki jumlah banyak dibandingkan dengan jeruk diploid (Jaskani et al., 2002). Evaluasi keragaman stomata penting untuk menganalisa hubungan antara stomata dengan aktivitas fisiologi seperti fotosintesis, kehilangan air, petumbuhan tanaman, karakter hasil dan hasil produksi. Evaluasi keragaman stomata beberapa genotipe okra penting koleksi PKHT dan Departemen AGH dapat dilakukan untuk menganalisa karakter anatomi stomata antara tetua, fillial/ keturunan dan varietas pembanding. Keragaman stomata dapat digunakan sebagai karakter seleksi untuk karakter penting dalam program pemuliaan tanaman okra.

\section{BAHAN DAN METODE}

\section{Waktu dan Tempat}

Penelitian dilakukan di Laboratorium Pusat Kajian Hortikultura Tropika LPPM IPB dan Laboratorium mikroteknik Departemen Agronomi dan Hortikultura Fakultas Pertanian IPB pada bulan Pebruari 2018. Sampel berupa daun dari empat belas genotipe yaitu dua genotipe tetua (P1 dan P2), filial (tiga genotipe : Naila, Zahira, Zahira1), sembilan genotipe pembanding (B293, E004, B291, C127, C069, MC2, Stripe, OR01, dan Clemson).

Pengamatan karakter daun dilakukan pada karakter pada stomata yang terdiri dari panjang, diameter dan kerapatan stomata dengan menggunakan mikroskop trinokuler Olympus dengan software kamera digital DP 25 BSW dengan perbesaran 40x. Rancangan percobaan yang digunakan adalah Rancangan Kelompok Lengkap Teracak (RKLT) satu faktor yaitu genotipe okra dengan 3 ulangan. Jika nilai F-hitung berbeda nyata pada taraf 5\% maka dilanjutkan dengan uji BNJ 5\%. Pengujian tersebut menggunakan Software SAS. Pengamatan stomata dilakukan dengan membuat sayatan paradermal. Tahapan preparat antara lain daun difiksasi dalam 70\% alkohol, kemudian dicuci dengan aquades, selanjutnya lapisan epidermis dilepaskan dari jaringan mesofil dengan menggunakan pisau silet. Lapisan epidermis tersebut diletakkan pada gelas objek dengan ditambahkan medium gliserin, kemudian ditutup dengan gelas penutup. Preparat diamati di bawah mikroskop trinokuler Olympus dengan software kamera digital DP 25 BSW dengan perbesaran 40x. Karakter yang diamati adalah (1) tipe stomata, (2) panjang stomata, (3) diameter stomata, (4) bentuk sel epidermis permukaan atas daun, (5) bentuk sel epidermis permukaan bawah daun dan (6) keberadaan stomata di permukaan atas maupun bawah permukaan daun. Data panjang dan diameter stomata merupakan nilai rata-rata dari pengukuran 3 ulangan bidang pandang yang dipilih secara acak. Setiap satu ulangan bidang pandang terdiri dari 3 buah stomata yang diamati yaitu 2 buah yang berukuran terbesar dan 1 buah yang berukuran terkecil. Parameter yang diamati pada sayatan paradermal daun ialah stomata berupa ukuran, tipe, indeks, dan kerapatan stomata. Sampel diamati pada 3 bidang pandang pada setiap ulangan. Penentuan indeks dan kerapatan stomata (Willmer, 1983) dihitung dengan rumus:

kerapatan stomata $=\frac{\sum \text { stomata }}{\text { luas bidang pandang }\left(\mathrm{mm}^{2}\right)}$
indeks stomata $=\frac{\sum \text { stomata }}{\sum \text { stomata }+\sum \text { sel epidermis }} \times 100$

Luas bidang pandang $=\pi \mathrm{r}^{2}$

Keterangan $: \mathrm{r}=$ jari-jari mikrometer objektif, $\pi=$ konstanta (3.14), luas bidang pandang pada perbesaran 40x $=0.196$ $\mathrm{mm}^{2}$.

\section{HASIL DAN PEMBAHASAN}

Daun merupakan salah satu organ yang mendapatkan dampak langsung dari pengaruh lingkungan, terutama dari radiasi cahaya matahari. Cahaya matahari langsung digunakan oleh daun untuk proses fotosintesis. Salinitas dan radiasi sinar matahari direspon oleh tumbuhan dan terwujud dalam bentuk adaptasi morfologis maupun anatomis. Pengamatan panjang dan lebar stomata dilakukan dengan menggunakan mikroskop pada perbesaran 40x. Hasil pengamatan analisis keragaman (Anova) pada empat belas genotipe okra diperoleh pada analisis panjang dan lebar stomata menunjukan berbeda sangat nyata pada tarafalpa $1 \%$ (Tabel 1). Ukuran panjang dan lebar stomata setiap genotipe berbeda-beda, sehingga dapat diuji lanjut menggunakan uji Duncan pada taraf alpa 5\%. Hasil rekapitulasi sidik ragam menunjukkan bahwa genotipe okra yang diuji berpengaruh sangat nyata pada karakter panjang stomata, diameter stomata, jumlah epidermis, jumlah kloroplas, jumlah stomata, index stomata dan kerapatan stomata pada taraf alpa $1 \%$. Karakter, panjang epidermis, dan diameter epidermis menunjukan tidak berbeda nyata (Tabel 1). 
Berdasakan hasil uji lanjut (Tabel 2) diperoleh genotipe OR01 memiliki stomata terpanjang $(34.784 \mu \mathrm{m})$ dan Clemson memiliki stomata terpendek $(25.974 \mu \mathrm{m})$. Tetua P1 $(31.086 \mu \mathrm{m})$ dan P2 $(31.626 \mu \mathrm{m})$ memiliki panjang stomata yang tidak berbeda nyata dengan genotipe Naila (32.488 $\mu \mathrm{m})$ dan Zahira $(29.517 \mu \mathrm{m})$. Karakter jumlah epidermis menunjukan tetua P1 (100.00) dan P2 (91.67) tidak berbeda nyata dengan genotipe Naila (101.00) dan Zahira (106.33). Karakter diameter stomata terlebar terdapat pada tetua P2

Tabel 1. Rekapitulasi signifikansi 9 karakter pada hasil pengamatan anatomi daun

\begin{tabular}{lcc}
\hline \multicolumn{1}{c}{ Karakter } & Signifikansi & KK \\
\hline Panjang stomata & $* *$ & 5.44 \\
Diameter stomata & $* *$ & 9.89 \\
Jumlah epidermis & $* *$ & 10.69 \\
Panjang epidermis & tn & 22.05 \\
Diameter epidermis & tn & 33.2 \\
Jumlah kloroplas & $* *$ & 15.84 \\
Jumlah stomata & $* *$ & 7.43 \\
Index stomata & $* *$ & 8.42 \\
Kerapatan stomata & $* *$ & 7.43 \\
\hline
\end{tabular}

Keterangan: $* *=$ berbeda nyata pada taraf peluang $0.01, *=$ berbeda nyata pada taraf peluang 0.05 , tn $=$ tidak berbeda nyata. $\mathrm{KK}=$ koefisien keragaman

Tabel 2. Hasil uji lanjut panjang stomata,diameter stomata dan jumlah epidermis

\begin{tabular}{lccc}
\hline \multicolumn{1}{c}{ Genotipe } & $\begin{array}{c}\text { Panjang } \\
\text { stomata }(\mu \mathrm{m})\end{array}$ & $\begin{array}{c}\text { Diameter } \\
\text { stomata }(\mu \mathrm{m})\end{array}$ & $\begin{array}{c}\text { Jumlah } \\
\text { epidermis }\end{array}$ \\
\hline P1 & $31086^{\mathrm{bcd}}$ & $24351^{\mathrm{ab}}$ & $100.00^{\mathrm{abcd}}$ \\
P2 & $31626^{\mathrm{abcd}}$ & $26355^{\mathrm{a}}$ & $91.67^{\mathrm{bcd}}$ \\
B293 & $31611^{\mathrm{abcd}}$ & $26342^{\mathrm{a}}$ & $114.67^{\mathrm{a}}$ \\
E004 & $33102^{\mathrm{ab}}$ & $26283^{\mathrm{a}}$ & $111.67^{\mathrm{ab}}$ \\
Naila & $32488^{\mathrm{abc}}$ & $24892^{\mathrm{ab}}$ & $101.00^{\mathrm{abcd}}$ \\
Clemson & $25974^{\mathrm{e}}$ & $24841^{\mathrm{ab}}$ & $104.00^{\mathrm{abcd}}$ \\
B291 & $34317^{\mathrm{a}}$ & $23616^{\mathrm{ab}}$ & $109.33^{\mathrm{abc}}$ \\
Zahira1 & $28998^{\mathrm{de}}$ & $20879^{\mathrm{bc}}$ & $88.67^{\mathrm{cd}}$ \\
C127 & $32902^{\mathrm{ab}}$ & $21528^{\mathrm{bc}}$ & $107.33^{\mathrm{abc}}$ \\
Zahira & $29517^{\mathrm{cd}}$ & $23304^{\mathrm{abc}}$ & $106.33^{\mathrm{abc}}$ \\
C069 & $28777^{\mathrm{de}}$ & $20879^{\mathrm{bc}}$ & $119.00^{\mathrm{a}}$ \\
OR01 & $34784^{\mathrm{a}}$ & $20622^{\mathrm{bc}}$ & $84.00^{\mathrm{d}}$ \\
MC2 & $30866^{\mathrm{bcd}}$ & $19110^{\mathrm{cd}}$ & $117.67^{\mathrm{a}}$ \\
Stripe & $28835^{\mathrm{de}}$ & $16498^{\mathrm{d}}$ & $90.33^{\mathrm{bcd}}$ \\
\hline
\end{tabular}

Keterangan: angka-angka yang diikuti oleh huruf yang sama pada kolom yang sama menunjukan tidak berbeda nyata berdasarkan uji DMRT pada taraf $\alpha 5 \%$
$(26.355 \mu \mathrm{m})$ dan terkecil pada Stripe $(16.498 \mu \mathrm{m})$. Varietas Naila $(24.892 \mu \mathrm{m})$ tidak berbeda nyata dengan tetua P1 $(24.351 \mu \mathrm{m})$, dan tetua P1 tidak berbeda dengan varietas Zahira $(23304 \mu \mathrm{m})$ pada taraf alpa 5\%.

Varietas Naila dan Zahira menunjukan tidak berbeda nyata dengan varietas pembanding seperti C070 $(25.205 \mu \mathrm{m})$ dan Clemson $(24.841 \mu \mathrm{m})$. Tetua jantan P2 tidak berbeda nyata dengan B293 (26.342 $\mu \mathrm{m})$ dan E004 (26.283 $\mu \mathrm{m})$. Daun yang memiliki stomata yang besar mengakibatkan fotosintesis lebih tinggi dibandingkan dengan daun yang memiliki stomata kecil (Sarwar et al., 2013), sehingga Tetua jantan P2 tidak berbeda nyata dengan B293 (26.342 $\mu \mathrm{m})$ dan E004 (26.283 $\mu \mathrm{m})$ merupakan genotipe yang memiliki stomata yang besar, sedangkan genotipe Stripe $(16.498 \mu \mathrm{m})$ memiliki stomata kecil.

Fotosintesis adalah peristiwa penangkapan energi yang berasal dari cahaya matahari oleh hijau daun untuk pembentukan bahan organik (Darmawan dan Baharsjah, 2010). Fotosintesis terjadi pada sel-sel tanaman yang berwarna hijau. Kloroplas tanaman tingkat tinggi mengandung klorofil A berwarna hijau kebiru-biruan $\left(\mathrm{C}_{55} \mathrm{H}_{72} \mathrm{O}_{5} \mathrm{~N}_{4} \mathrm{Mg}\right)$ dan klorofil $\mathrm{B}$ berwarna hijau kekuningkuningan $\left(\mathrm{C}_{55} \mathrm{H}_{70} \mathrm{O}_{6} \mathrm{~N}_{4} \mathrm{Mg}\right)$. Pembentukan klorofil dapat dipengaruhi oleh faktor keturunan, ketersediaan oksigen, karbohidrat, unsur lain (N, Mg, Fe dan Mn) serta cahaya (Darmawan dan Baharsjah, 2010). Jumlah kloroplas tetua jantan P2 menunjukan nilai terendah (2.667) sebagai tetua pemberi karakter warna ungu. Varietas Naila menunjukan jumlah kloroplas yang tidak berbeda dengan tetua P2, meskipun keragaan varietas Naila memiliki daun, batang

Tabel 3. Hasil uji lanjut jumlah kloroplas, jumlah stomata, index stomata dan kerapatan stomata

\begin{tabular}{lcccc}
\hline Genotipe & $\begin{array}{c}\text { Jumlah } \\
\text { Kloroplas }\end{array}$ & $\begin{array}{c}\text { Jumlah } \\
\text { stomata }\end{array}$ & $\begin{array}{c}\text { Index } \\
\text { stomata }\end{array}$ & $\begin{array}{c}\text { Kerapatan } \\
\text { stomata }\left(\mathrm{mm}^{2}\right)\end{array}$ \\
\hline P1 & $11.000 \mathrm{abc}$ & $67.667^{\mathrm{a}}$ & $40.31^{\mathrm{a}}$ & $345.24^{\mathrm{a}}$ \\
P2 & $2.667 \mathrm{e}$ & $50.333^{\mathrm{cde}}$ & $35.69^{\mathrm{abc}}$ & $256.80^{\mathrm{cde}}$ \\
B293 & $11.000 \mathrm{abc}$ & $57.000^{\mathrm{bc}}$ & $33.20^{\mathrm{bc}}$ & $290.82^{\mathrm{bc}}$ \\
E004 & $11.000 \mathrm{abc}$ & $43.667^{\mathrm{efg}}$ & $28.31^{\mathrm{de}}$ & $222.79^{\mathrm{fg}}$ \\
Naila & $7.333 \mathrm{~d}$ & $40.000^{\mathrm{fg}}$ & $28.37^{\mathrm{de}}$ & $204.08^{\mathrm{fg}}$ \\
Clemson & $11.333 \mathrm{ab}$ & $68.000^{\mathrm{a}}$ & $39.50^{\mathrm{ab}}$ & $346.94^{\mathrm{a}}$ \\
B291 & $11.667 \mathrm{ab}$ & $38.333^{\mathrm{g}}$ & $25.95^{\mathrm{e}}$ & $195.58^{\mathrm{g}}$ \\
Zahira1 & $9.333 \mathrm{bcd}$ & $50.667^{\mathrm{cde}}$ & $32.78^{\mathrm{cd}}$ & $258.50^{\mathrm{cde}}$ \\
C127 & $13.667 \mathrm{a}$ & $51.000^{\mathrm{cd}}$ & $32.29^{\mathrm{cd}}$ & $260.20^{\mathrm{cd}}$ \\
Zahira & $9.000 \mathrm{bcd}$ & $52.000^{\mathrm{cd}}$ & $36.96^{\mathrm{abc}}$ & $265.31^{\mathrm{cd}}$ \\
C069 & $11.667 \mathrm{ab}$ & $62.667^{\mathrm{ab}}$ & $34.55^{\mathrm{bc}}$ & $319.73^{\mathrm{ab}}$ \\
OR01 & $8.000 \mathrm{~cd}$ & $57.667^{\mathrm{bc}}$ & $40.91^{\mathrm{a}}$ & $294.22^{\mathrm{bc}}$ \\
MC2 & $10.000 \mathrm{bcd}$ & $46.667^{\mathrm{def}}$ & $28.41^{\mathrm{de}}$ & $238.09^{\mathrm{def}}$ \\
Stripe & $11.000 \mathrm{abc}$ & $54.000^{\mathrm{dc}}$ & $37.40^{\mathrm{abc}}$ & $275.51^{\mathrm{cd}}$ \\
\hline
\end{tabular}

Keterangan: angka-angka yang diikuti oleh huruf yang sama pada kolom yang sama menunjukan tidak berbeda nyata berdasarkan uji DMRT pada taraf $\alpha 5 \%$ 
dan buah muda berwarna hijau. Varietas Zahira (9.000) tidak berbeda jumlah kloroplasnya dengan tetua P1 (11.000). Varietas pembanding C127 memiliki jumlah kloroplas terbanyak dan berbeda dengan P1, P2, Naila dan Zahira. Varietas Clemson sebagai varietas pembanding menunjukan jumlah stomata terbanyak (68.000). Jumlah stomata tetua P2 (50.333) tidak berbeda nyata dengan varietas Zahira (52.000). Varietas Naila memiliki jumlah stomata terendah dibandingkan dengan P1 (67.667)dan P2 (50.333). Jumlah stomata berkorelasi nyata terhadap produksi karena jumlah stomata berhubungan dengan fotosintesis (Sarwar et.al., 2013).

Nilai index stomata genotipe P1 mencapai 40.31. Genotipe Naila memiliki index stomata rendah (28.37) dan berbeda nyata dengan tetua P1 (40.31), sedangkan genotipe Zahira (36.96) tidak berbeda nyata dengan tetua P2 (35.69). Genotipe OR01 memiliki index stomata sebesar 40.91 dan tidak berbeda nyata dengan tetua P1 (Tabel 3). Kerapatan stomata P1 menunjukan nilai yang tertinggi $\left(345.24 \mathrm{~mm}^{2}\right)$, sedangkan tetua P2 mencapai $256.80 \mathrm{~mm}^{2}$. Tetua P2 tidak berbeda nyata untuk kerapatan stomata dengan genotipe Zahira $\left(265.31 \mathrm{~mm}^{2}\right)$ dan Naila $\left(204.08 \mathrm{~mm}^{2}\right)$. Jumlah dan ukuran stomata berpengaruh langsung terhadap fotosintesis. Hasil fotosintesis yang tinggi berpengaruh terhadap produksi hasil panen (Avci dan Aygun, 2014). Produksi yang rendah dapat dipengaruhi oleh kerapatan sel epidermis yang besar, tetapi kerapatan stomata yang rendah dapat meningkatkan efisiensi penggunanaan air, dan index stomata yang tinggi dapat meningkatkan fotosintesis dan hasil produksi, seperti pada gandum dapat berproduksi tinggi pada genotipe yang memiliki kerapatan stomata rendah dan index stomata yang tinggi (Liao et.al., 2005).

Pengamatan stomata pada permukaan atas maupun permukaan bawah daun merupakan peubah pada pengamatan morfologi. Stomata adalah celah dalam epidermis yang dibatasi oleh dua sel penutup berbentuk ginjal, sedangkan sel yang berbeda bentuknya disebut sel tetangga. Bentuk sisi sel epidermis bervariasi seperti berleluk dalam, berlekuk

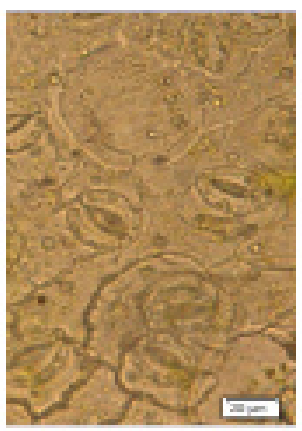

P1

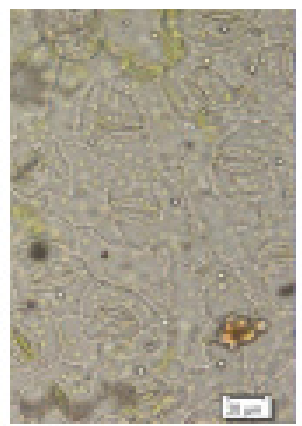

Stripe

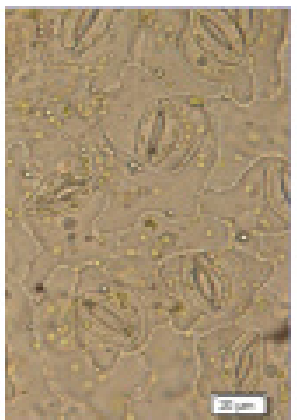

C127

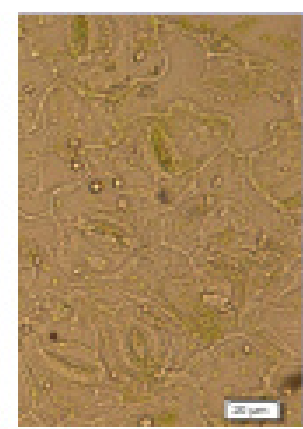

P2

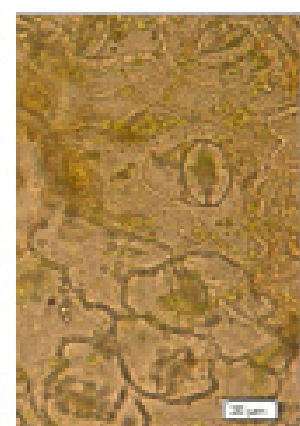

MC2

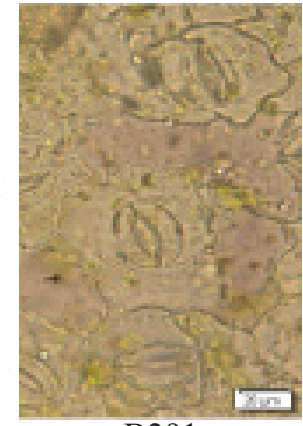

B291

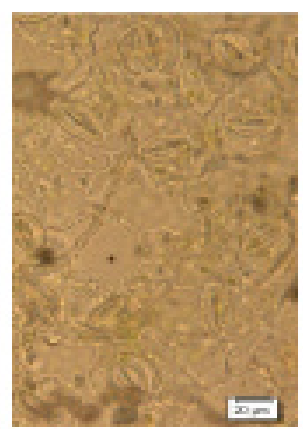

Zahira1

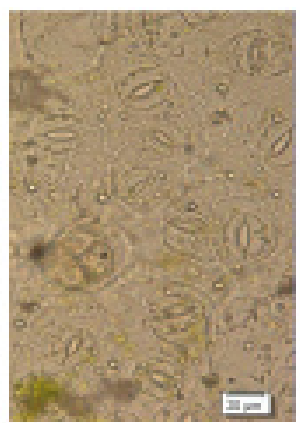

Clemson

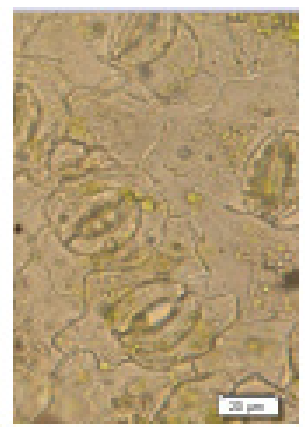

E004

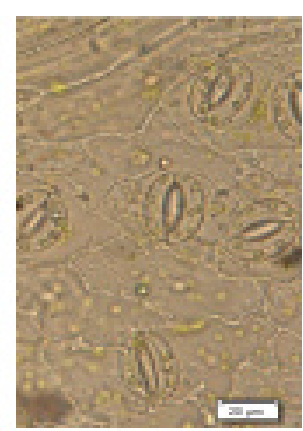

Zahira

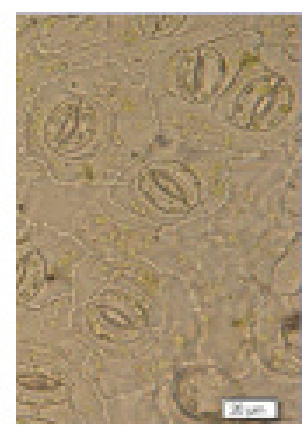

C069

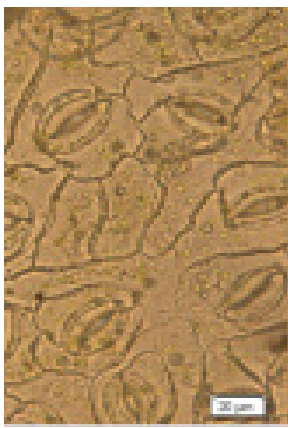

OR01

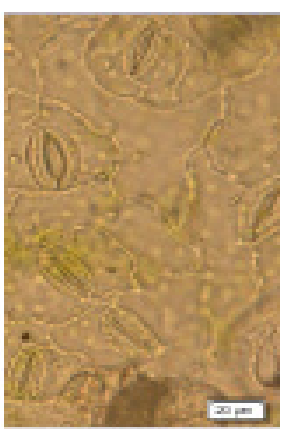

Naila

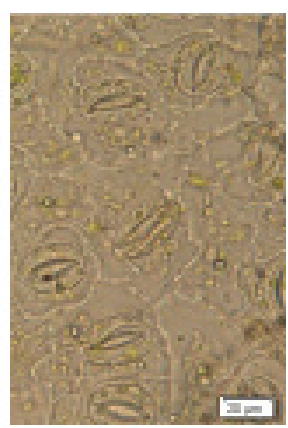

B293

Gambar 1. Karakter tipe stomata dan sel epidermis bagian bawah permukaan daun 14 genotipe okra 
dangkal atau rata. Menurut Tabrani et al. (1989) bentuk dinding sel epidermis terdiri dari berlekuk-lekuk, berombak dan beralun. Sel epidermis yang mengelilingi sel penutup dapat digunakan sebagai identifikasi dari tipe stomata. Tipe stomata dapat dibedakan menjadi 4, berdasarkan susunan sel epidermis yang berada di samping sel penutup yaitu : (1) anomositik apabila sel penutup dikelilingi oleh sel yang tidak dapat dibedakan ukuran dan bentuknya dengan sel epidermis, (2) anisositik apabila sel penutup dikelilingi tiga buah sel tetangga yang tidak sama besar, (3) parasitik apabila sel penutup diringi satu atau lebih oleh sel tetangga yang sejajar dengan sel penutup dan (4) diasitik apabila stomata dikelilingi oleh dua sel tetangga yang letaknya tegak lurus (Hidayat, 1995). Pada umumnya 14 genotipe memiliki stomata bertipe anomositik karena sel penutup dikelilingi oleh sel yang tidak dapat dibedakan ukuran dan bentuk sel epidermis berlekuk dangkal (Gambar 1).

\section{KESIMPULAN}

Evaluasi keragaman stomata empat belas genotipe okra menunjukkan bahwa genotipe okra yang diuji berpengaruh sangat nyata pada karakter panjang stomata, diameter stomata, jumlah epidermis, jumlah kloroplas, jumlah stomata, index stomata dan kerapatan stomata pada taraf alpa 1\%. Jumlah kloroplas tetua jantan P2 menunjukan nilai terendah (2.667) sebagai tetua pemberi karakter warna ungu. Varietas Naila menunjukan jumlah kloroplas yang tidak berbeda dengan tetua P2, meskipun keragaan varietas Naila memiliki daun, batang dan buah muda berwarna hijau. Varietas Zahira (9.000) tidak berbeda jumlah kloroplasnya dengan tetua P1 (11.000).

Kerapatan stomata tetua P2 mencapai $256.80 \mathrm{~mm}^{2}$ dan tidak berbeda nyata dengan genotipe Zahira $\left(265.31 \mathrm{~mm}^{2}\right)$ dan Naila (204.08 $\mathrm{mm}^{2}$ ). Tetua P2, Zahira dan Naila memiliki kerapatan stomata yang rendah sehingga meningkatkan efisiensi penggunanaan air. Index stomata yang tinggi dapat meningkatkan fotosintesis dan hasil produksi. Nilai index stomata genotipe tetua P1 (40.31) dan P2 (35.69) tinggi, sedangkan genotipe Naila memiliki index stomata rendah (28.37), sedangkan genotipe Zahira (36.96) tidak berbeda nyata dengan tetua $\mathrm{P} 2$.

\section{DAFTAR PUSTAKA}

Avci, N., A. Aygun. 2014. Determination of stomatal density and distribution on leaves of Turkish Hazelnut (Corylus avellana L.) cultivars. Tarım Bilimleri Dergisi J. of Agricultural Sciences Vol. 20:454-459.
Damayanti, F. 2007. Analisis jumlah kromosom dan anatomi stomata pada beberapa plasma nutfah pisang ( $M u s a$ SP.) Asal Kalimantan Timur. Bioscientiae. Volume 4 (2) :53-61.

Darmawan, J., J.S. Baharsjah. 2010. Dasar-dasar Fisiologi Tanaman. SITC, Jakarta. 86 Hal.

Hafiz, P., Dorly, S. Rahayu. 2013. Karakteristik anatomi daun dari sepuluh species Hoya sukulen serta analisis hubungan kekerabatannya. Buletin Kebun Raya Vol. 16 No. 1.

Hidayat, E.B. 1995. Anatomi Tumbuhan Berbunga. Bandung. Institut Teknologi Bandung.

Ikrarwati, N.A. Rokhmah. 2016. Budidaya Okra dan Kelor dalam Pot. Balai Pengkajian Teknologi Pertanian (BPTP) Jakarta. Balai Besar Pengkajian dan Pengembangan Teknologi Pertanian Badan Penelitian dan Pengembangan Pertanian Kementerian Pertanian.

Jaskani, M.J., M.M. Khan, I.A. Khan. 2002. Growth, morfology and fruit comparison of diploid and tetraploid Kinnow Mandarin. Pak J Agri. Sci, Vol $39(2)$.

Liao, J.X., J. Chang, G.X. Wang. 2005. Stomatal density and gas exchange in six wheat cultivars. Cereal Research Communications. Vol. 33(4).

Priya, T.B., B.N.S. Murthy, S. Jagannath. 2016. Role of stomatal frequency in plant innate immunity against Bacterial blight disease of Pomegranate. Int. J. of Agric. Sci. and Research (IJASR) Vol. 6(4):161-164.

Sarwar, A.K.M.G., M.A. Karim, S.M.A.M. Rana. 2013. Influence of stomatal characteristics on yield and yield attributes of. Rice. J. Bangladesh Agril. Univ. 11(1):47-52.

Tabrani, G., A. Setiawan, E.A. Widjaja. 1989. Anatomi buluh jenis-jenis Schizostachyum koleksi Kebun Raya Bogor. Floribunda 1(11):41-44.

Willmer, C.M. 1983. Stomata. London: Longman Group limited. 